This is the peer reviewed version of the following article: Z. Anorg. Allg . Chem. 2018, 644, 1028-1033,

which has been published in final form at: https://doi.org/10.1002/zaac.201800204

ARTICLE

DOI: 10.1002/zaac.200((will be filled in by the editorial staff))

\title{
Synthesis and X-ray crystal structures of Ga-substituted distibenes $[\mathrm{L}(\mathrm{X}) \mathrm{GaSb}]_{2}$
}

\author{
Julia Krüger, Juliane Schoening, Chelladurai Ganesamoorthy, Lukas John, Christoph Wölper, \\ and Stephan Schulz*
}

Dedicated to Prof. A. Filippou on the occasion of his 60th birthday.

Keywords: Antimony, Gallium, Multiple Bonds, X-ray Diffraction

The reactions of two equivalents of $\mathrm{LGa}\{\mathrm{L}=\mathrm{HC}[\mathrm{C}(\mathrm{Me}) \mathrm{N}(2,6-i-$ $\left.\left.\left.\operatorname{Pr}_{2} \mathrm{C}_{6} \mathrm{H}_{3}\right)\right]_{2}\right\}$ with $\mathrm{SbX}_{3}(\mathrm{X}=\mathrm{Br}, \mathrm{I}, \mathrm{OEt})$ proceed with elimination of $\mathrm{LGaX}_{2}$ and formation of Ga-substituted distibenes [L(X)GaSb] 2 (X
$=\operatorname{Br} \mathbf{1}, \mathrm{I} \mathbf{2}$, OEt $\mathbf{3})$. 1 to $\mathbf{3}$ were characterized by heteronuclear NMR $\left({ }^{1} \mathrm{H},{ }^{13} \mathrm{C}\right)$, IR and UV/VIS spectroscopy, elemental analysis and single crystal X-ray diffraction.

\footnotetext{
* Prof. Dr. Stephan Schulz

Fax: + 49 0201-1834635, Phone: + 4902011834635 stephan.schulz@uni-due.de

Faculty of Chemistry and Center for Nanointegration

Đ Duisburg-Essen (CENIDE), University of Duisburg-Essen,

45117 Essen, Germany

E-mail: Homepage: http://www.uni-due.de/ak_schulz/ Supporting information for this article is available on the WWW under http://dx.doi.org/10.1002/zaac.201000xxx or from the author.
}

\section{Introduction}

The interest in heavier main group element compounds containing an element-element double bond received a tremendous boost in the early 80 ies of the last century, when West et al. ${ }^{[1]}$ and Joshifuji et al. ${ }^{[2]}$ reported on the first compounds containing $\mathrm{Si}=\mathrm{Si}$ and $\mathrm{P}=\mathrm{P}$ double bonds, respectively. Since then, numerous main group element compounds of group 13 to 16 elements containing homoleptic or heteroleptic double and triple bonds, which violate the socalled double bond rule, ${ }^{[3]}$ according to which the formation of $\pi$-bonds is restricted to elements of the second row of the periodic table, have been reported ${ }^{[4]}$ their bonding situation analysed by quantum chemical calculation ${ }^{[5]}$ and their interesting reactivity in particular in small molecule activation reactions studied. ${ }^{[6]}$ In case of group 15 compounds, double-bonded species of the general type $\mathrm{RE}=\mathrm{ER}$ have been kinetically stabilized by use of sterically encumbered organic substituents (scheme 1). ${ }^{[7]}$ However, the low number of structurally characterized compounds of the type $R_{2} E_{2}$ (without transition metal complexes) containing As=As (11), $\mathrm{Sb}=\mathrm{Sb}$ (7) and $\mathrm{Bi}=\mathrm{Bi}$ (12) double bonds ${ }^{[8]}$ compared to diphosphenes containing a $\mathrm{P}=\mathrm{P}$ double bond $\left.(>75)^{[9]}\right]$ indicate the lower bond strength of the $\mathrm{E}=\mathrm{E}$ double bond of heavier group 15 elements, resulting from the decreasing $\pi$-bond energy. ${ }^{[10]}$ In addition, NHC-stabilized $(\mathrm{NHC}=\mathrm{N}$ heterocyclic carbene) diatomic molecules of the type $(\mathrm{NHC})_{2} \mathrm{E}_{2}(\mathrm{E}=\mathrm{P}, \mathrm{As}, \mathrm{Sb})$, which formally contain the group 15 elements in the oxidation state 0 , were prepared, ${ }^{[11]}$ but these exhibit E-E single bonds.
Distibenes have been kinetically-stabilized by use of sterically demanding substituents (scheme 1) $)^{[12]}$ Their electronic situation was investigated by quantum chemical calculation $^{[13]}$ and their chemical reactivity was studied in detail, ${ }^{[14]}$ i.e. their coordination ability toward transition metals ${ }^{[15]}$ and their reactivity in single electron reduction reactions, that yielded the corresponding radical anion, ${ }^{[16]}$ respectively.

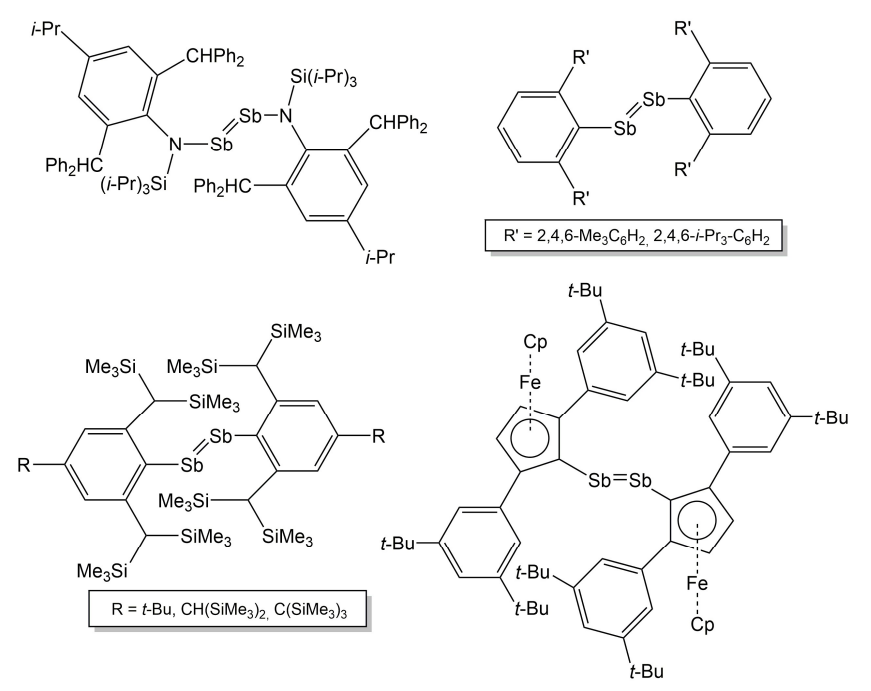

Scheme 1 . Structurally characterized distibenes $\mathrm{R}_{2} \mathrm{Sb}_{2}$ containing a $\mathrm{Sb}=\mathrm{Sb}$ double bond.

We recently observed that reactions of two equivalents of monovalent gallanediyl LGa $\{\mathrm{L}=\mathrm{HC}[\mathrm{C}(\mathrm{Me}) \mathrm{N}(2,6-i-$ $\left.\left.\left.\mathrm{Pr}_{2} \mathrm{C}_{6} \mathrm{H}_{3}\right)\right]_{2}\right\}$ with $\mathrm{EX}_{3}\left(\mathrm{E}=\mathrm{As}, \mathrm{Sb}, \mathrm{Bi} ; \mathrm{X}=\mathrm{Cl}, \mathrm{NR}_{2}\right)$ yielded the corresponding Ga-substituted dipnictenes $[\mathrm{L}(\mathrm{X}) \mathrm{GaE}]_{2}$ with a central $\mathrm{E}=\mathrm{E}$ double bond, under mild reaction conditions. ${ }^{[17]}$ Upon heating, the distibenes $[\mathrm{L}(\mathrm{X}) \mathrm{GaSb}]_{2}$, were converted into $\mathrm{Sb}$ analogues of bicyclo[1.1.0]butane $[\mathrm{L}(\mathrm{X}) \mathrm{Ga}]_{2}\left(\mu, \eta^{1: 1}-\mathrm{Sb}_{4}\right)\left(\mathrm{X}=\mathrm{Cl}, \mathrm{NMe}_{2}, \mathrm{NMeEt}\right)$. 
To further prove the influence of the $\mathrm{X}$ substituent on the reactivity of the starting antimonides $\mathrm{SbX}_{3}$, we systematically investigated reaction of two equivalents of $\mathrm{LGa}$ with two antimony trihalides $\mathrm{SbX}_{3}(\mathrm{X}=\mathrm{Br}, \mathrm{I})$ and antimony triethoxide $\mathrm{Sb}(\mathrm{OEt})_{3}$, respectively. The resulting Gasubstituted distibenes $[\mathrm{L}(\mathrm{X}) \mathrm{GaSb}]_{2}(\mathrm{X}=\mathrm{Br} \mathbf{1}$, I 2, OEt 3) were characterized by heteronuclear $\left({ }^{1} \mathrm{H},{ }^{13} \mathrm{C}\right)$ NMR spectroscopy and single crystal X-ray diffraction and the structural parameters within this class of compounds are compared. In addition, quantum chemical calculations were performed to investigate the electronic structure of $\mathbf{1}$ - $\mathbf{3}$.

\section{Results and Discussion}

Reactions of two equivalents of $\mathrm{LGa}$ with $\mathrm{SbX}_{3}$ in toluene at ambient temperature proceeded with elimination of $\mathrm{LGaX}_{2}$ (X $=\mathrm{Br}, \mathrm{I}, \mathrm{OEt})$, as was proven by in situ ${ }^{1} \mathrm{H}$ NMR spectroscopy, and formation of the Ga-substituted distibenes $[\mathrm{L}(\mathrm{X}) \mathrm{GaSb}]_{2}(\mathrm{X}=\mathrm{Br} \mathbf{1}, \mathrm{I}$ 2, OEt 3), which were isolated in high yields as green crystalline solids after recrystallization from solutions in toluene at ambient temperature.

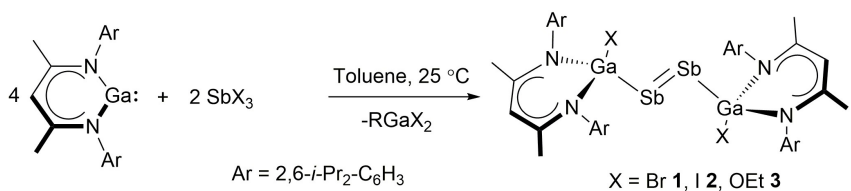

Scheme 3. Synthesis of $\mathbf{1}$ to $\mathbf{3}$.

$\mathbf{1}-\mathbf{3}$ are soluble in benzene and toluene and can be stored in solution and as isolated crystals under argon atmosphere at ambient temperature. The ${ }^{1} \mathrm{H}$ NMR spectra of $\mathbf{1}-\mathbf{3}$ in benzene- $d_{6}$ show two septets and four doublets for the magnetically inequivalent $i$-Pr groups of the $\beta$-diketiminate ligand and single resonances for the $\gamma-\mathrm{CH}$ and the methyl groups of the $\mathrm{C}_{3} \mathrm{~N}_{2} \mathrm{M}$ ring, whereas the ${ }^{13} \mathrm{C}$ NMR spectra of 1 -3 each show 14 signals of the $\beta$-diketiminate groups (Table 1). Comparable findings were reported for dipnictenes of the general type $[\mathrm{L}(\mathrm{Cl}) \mathrm{GaE}]_{2}\left(\mathrm{E}=\mathrm{As},{ }^{[17 \mathrm{c}]} \mathrm{Sb}^{[17 \mathrm{~b}]}\right)$.

Table 1. ${ }^{1} \mathrm{H}$ NMR chemical shifts of $[\mathrm{L}(\mathrm{X}) \mathrm{GaSb}]_{2}{ }^{[\mathrm{a}]}$

\begin{tabular}{|c|c|c|c|c|}
\hline$X=$ & $\gamma-\mathrm{CH}$ & $\mathrm{CHMe}$ & СНМе2 & CMe \\
\hline $\mathrm{Cl}^{[17 b]}$ & 4.97 & $3.91,3.05$ & $\begin{array}{l}1.30,1.20 \\
1.11,1.01\end{array}$ & 1.63 \\
\hline $\mathrm{Br} 1$ & 5.00 & $3.98,3.05$ & $\begin{array}{l}1.40,1.20 \\
1.12,0.99\end{array}$ & 1.63 \\
\hline I 2 & 5.06 & $4.04,3.05$ & $\begin{array}{l}1.42,1.21 \\
1.14,0.97\end{array}$ & 1.62 \\
\hline OEt 3 & 4.82 & $4.02,2.99$ & $\begin{array}{l}1.51,1.39 \\
1.29,1.04\end{array}$ & 1.62 \\
\hline $\mathrm{NMe}_{2}{ }^{[17 \mathrm{a}]}$ & 4.75 & $3.62,2.90$ & $\begin{array}{l}1.35,1.29 \\
1.02,1.00\end{array}$ & 1.61 \\
\hline $\mathrm{NMeEt}^{[17 \mathrm{~b}]}$ & 4.78 & $\begin{array}{l}3.95,3.82, \\
2.90\end{array}$ & $\begin{array}{l}1.32,1.28 \\
1.03,1.01\end{array}$ & 1.61 \\
\hline
\end{tabular}

[a] $300 \mathrm{MHz}, 25^{\circ} \mathrm{C}$, benzene- $\mathrm{d}_{6}$.

The UV/VIS spectra of solutions of $\mathbf{1}$ - $\mathbf{3}$ in toluene (Fig. S12) each show a maximum absorption at $354 \mathrm{~nm}$, which agrees very well with the value reported by Power et al. for
LGa $(340 \mathrm{~nm})^{[18]}$ and thus can be assigned to the $\mathrm{L}(\mathrm{X}) \mathrm{Ga}$ substituent, as well as a second absorption maximum at 437 (1) and $438 \mathrm{~nm}$ (2) due to the $\pi-\pi *$ transitions. Comparable values were previously reported for other distibenes $\mathrm{RSb}=\mathrm{SbR} .{ }^{[7 \mathrm{a}]}$ In contrast, no $\pi-\pi *$ absorption was observed for 3 .

Single crystals of $\mathbf{1}$ - $\mathbf{3}$ were obtained upon storage of solutions in toluene at ambient temperature after $2 \mathrm{~h} \mathrm{(1),} 3 \mathrm{~h}$ (2) and after $5 \mathrm{~d}$ at $-30{ }^{\circ} \mathrm{C}(3) .1$ and 2 crystallize in the triclinic space group $P-1$ with the molecule placed on centre of inversion, whereas 3 crystallizes in the monoclinic space group $P 2{ }_{1} / c$, respectively (Figs. $1-3$ ). ${ }^{[19]}$

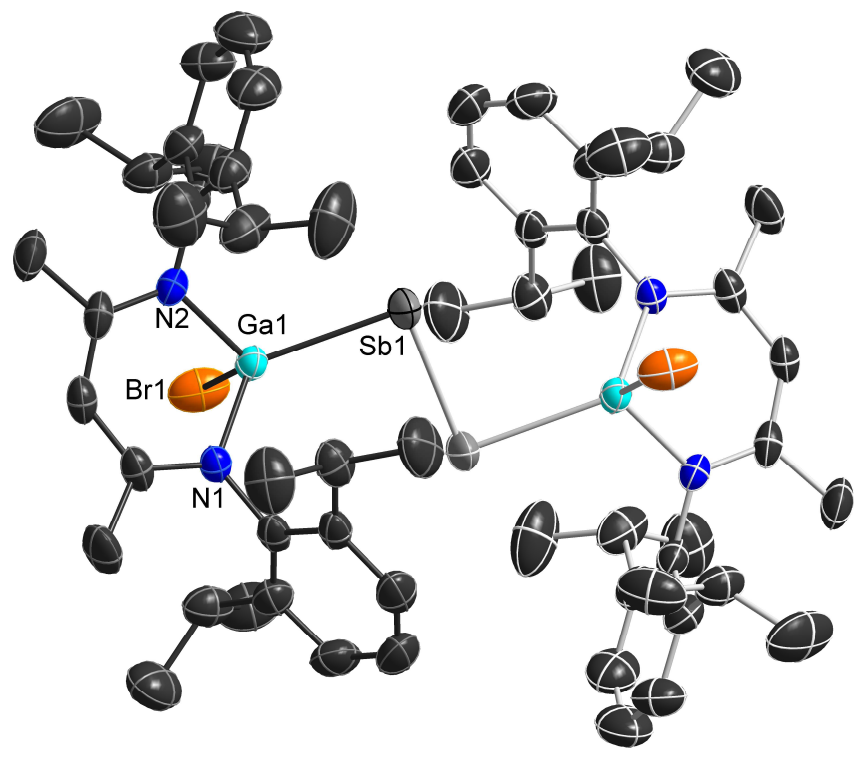

Figure 1. Solid state structure of $\mathbf{1}$. Non-H-atoms shown as thermal ellipsoids at $50 \%$ probability levels, hydrogen atoms omitted for clarity. Part depicted in pale colors is generated by symmetry.

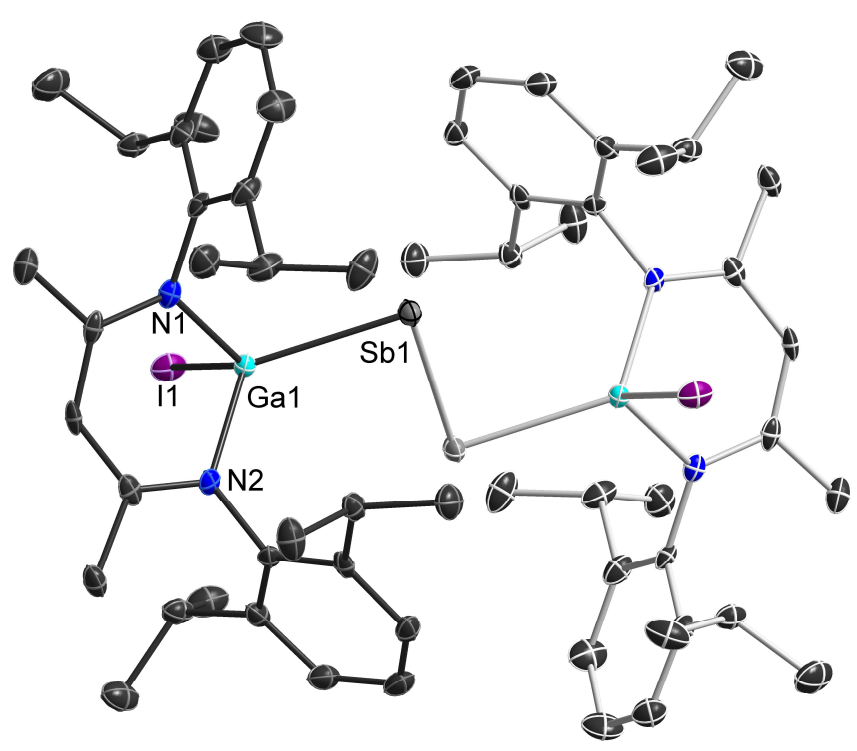

Figure 2. Solid state structure of 2. Non-H-atoms shown as thermal ellipsoids at $50 \%$ probability levels; hydrogen atoms omitted for clarity. Part depicted in pale colors is generated by symmetry. 
The centrosymmetric $(\mathbf{1}, \mathbf{2}) \mathrm{Sb}_{2}$ units are coordinated by two LGaX groups (X = Br 1, I 2, OEt 3) in a trans-bent orientation as is typically observed for distibenes. The $\mathrm{Ga}$ atoms are tetrahedrally coordinated and are slightly off the best plane of the ligand's backbone (1: 0.599(4) $\AA, 2$ : $0.583(3) \AA, 3: 0.593(5) \AA$ and $0.526(5) \AA)$. The Ga-X bond lengths $\left(\mathrm{X}=\mathrm{Cl} 2.2319(4) \AA,{ }^{[17 \mathrm{~b}]} \mathrm{Br} 2.4126(10) \AA\right.$ 1, I $2.6010(5) \AA 2)$ increase with increasing atomic number of the halogen atom (table 2) and the Ga-N bond lengths (1.965(3),

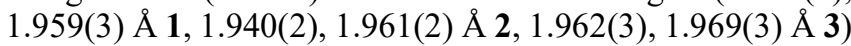
are significantly shorter compared to those in gallanediyl LGa $(2.0528(14) \AA, 2.0560(13) \AA)^{[18]}$ as is typically observed upon oxidation of the $\mathrm{Ga}$ atom in $\mathrm{LGa} .{ }^{[20]}$

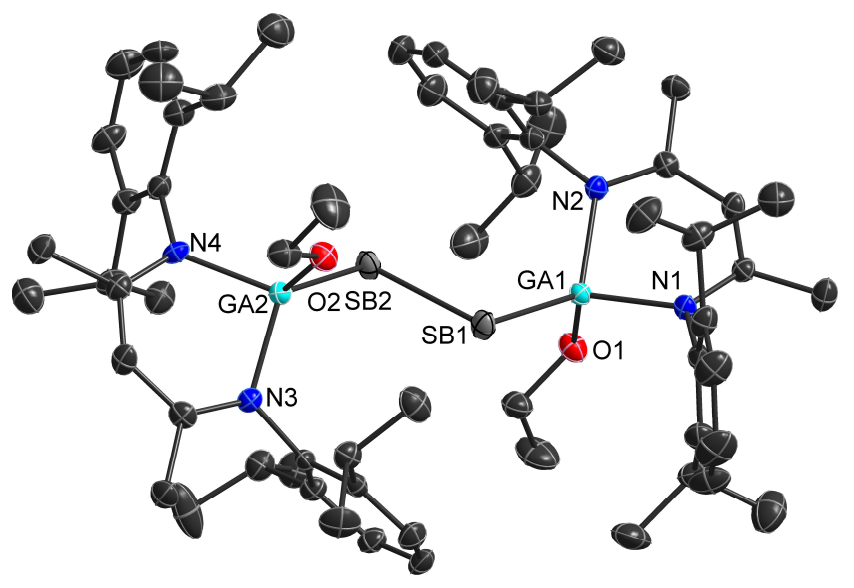

Figure 3. Solid state structure of $\mathbf{3}$. Non-H-atoms shown as thermal ellipsoids at $50 \%$ probability levels; hydrogen atoms omitted for clarity.

The central Sb-Sb bond lengths (1 2.6442(11) A, 2 2.6310(5) $\AA, 3$ 2.6495(4) $\AA$ ) are almost identical and agree very well with those of previously reported Ga-substituted distibenes $[\mathrm{L}(\mathrm{X}) \mathrm{GaSb}]_{2} \quad(\mathrm{X}=\mathrm{Cl}$ 2.6461(2) $\AA$, NMeEt $\left.2.6433(6) \AA,^{[17 b]} \mathrm{NMe}_{2} 2.6477(3) \AA^{[17 \mathrm{a}]}\right]$ and distibenes $\mathrm{RSb}=\mathrm{SbR}$ containing sterically demanding organic substituents, for which values from 2.64 to $2.70 \AA$ were reported. ${ }^{[21]}$ The $\mathrm{Sb}=\mathrm{Sb}$ double bonds are shorter than $\mathrm{Sb}-\mathrm{Sb}$ single bonds typically observed in distibines $\mathrm{R}_{4} \mathrm{Sb}_{2} \cdot{ }^{[22]}$ The $\mathrm{Sb}-\mathrm{Sb}$ bond length in the parent system, $\mathrm{HSb}=\mathrm{SbH}$, was calculated by different groups, yielding values between 2.608 $\AA$ and $2.682 \AA,{ }^{[23]}$ respectively. The $\mathrm{Ga}-\mathrm{Sb}$ bond lengths (1

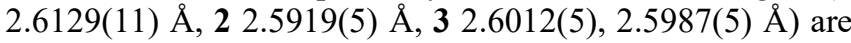
slightly shorter than the sum of the calculated single bond covalent radii for $\mathrm{Ga}(1.24 \AA)$ and $\mathrm{Sb}(1.40 \AA)$ atoms, ${ }^{[24]}$ but comparable to $\mathrm{Ga}-\mathrm{Sb}$ single bonds observed in other Gasubstituted distibenes $[\mathrm{L}(\mathrm{X}) \mathrm{GaSb}]_{2}(\mathrm{X}=\mathrm{Cl} 2.58178(19) \AA$, NMeEt 2.6169(5) $\left.\AA{ }^{[17 b]} \mathrm{NMe}_{2} 2.6200(4) \AA^{[17 \mathrm{a}]}\right)$, tetrastibines $\left[(\mathrm{LGaX})_{2}\left(\mu, \eta^{1: 1}-\mathrm{Sb}_{4}\right] \quad\left(\mathrm{X}=\mathrm{Cl} 2.6008(13) \AA,{ }^{[17 \mathrm{~b}]} \mathrm{NMe}_{2}\right.\right.$ $\left.2.5975(5) \AA^{[17 \mathrm{a}]}\right)$ as well as the stibanyl radical $[\mathrm{L}(\mathrm{Cl}) \mathrm{Ga}]_{2} \mathrm{Sb}$. [2.5899(4), 2.5909(3) $\AA] .{ }^{[25]}$ In contrast, Ga-Sb single bonds in $\quad\left[\left(\mathrm{L}^{\prime} \mathrm{Ga}\right)_{2}\left(\mu, \eta^{2: 2}-\mathrm{Sb}_{4}\right)\right] \quad(2.6637(11) \quad \AA),{ }^{[26]}$ dmap$\mathrm{Ga}(\mathrm{Et})_{2} \mathrm{Sb}\left(\mathrm{SiMe}_{3}\right)_{2} \quad\left(\mathrm{dmap}=4-\mathrm{Me}_{2} \mathrm{NC}_{5} \mathrm{H}_{4} \mathrm{~N}\right.$, 4-dimethylaminopyridine; $2.648(1) \AA)^{[27]}$ as well as in four- and sixmembered heterocycles $\left[\mathrm{R}_{2} \mathrm{GaSbR}_{2}\right]_{\mathrm{x}}$, which were found to range from $2.666 \AA$ to $2.772 \AA,{ }^{[28]}$ are slightly elongated. In contrast, gallastibenes of the general type $\mathrm{LGaSbGa}(\mathrm{X}) \mathrm{L}$, which contain a $\mathrm{Ga}=\mathrm{Sb}$ double bond, showed significantly

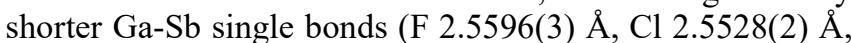
Br 2.5662(3) $\AA$, I 2.5478(6) $\AA$ ) and Ga-Sb double bonds (F

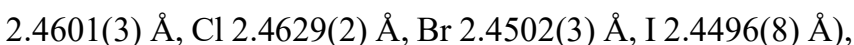
respectively. ${ }^{[25,29]}$ The Ga-Sb-Sb bond angles in $\mathbf{1}\left(90.92(3)^{\circ}\right)$, $2\left(89.685(15)^{\circ}\right)$ and $3\left(88.313(14)^{\circ}, 92.238(15)^{\circ}\right)$ agree almost perfectly with those in $[\mathrm{L}(\mathrm{Cl}) \mathrm{GaSb}]_{2}\left(89.476(6)^{\circ}\right),^{[17 b]}$ whereas those of the amido-substituted derivatives $[\mathrm{L}(\mathrm{X}) \mathrm{GaSb}]_{2} \quad\left(\mathrm{X}=\mathrm{NMeEt} \quad 95.839(16)^{\circ},{ }^{[17 b]} \mathrm{NMe}_{2}\right.$ $\left.94.710(8)^{\circ[17 \mathrm{a}]}\right)$ are slightly enlarged, most likely resulting from the higher steric demand of the amido substituents. In addition, the calculated $\mathrm{H}-\mathrm{Sb}-\mathrm{Sb}$ bond angle of $\mathrm{HSb}=\mathrm{SbH}$ $\left(93.0^{\circ}\right)^{[23]}$ falls in between these values. The $\mathrm{Ga}-\mathrm{Sb}-\mathrm{Sb}$ bond angles in $\mathbf{1}$ to $\mathbf{3}$, which are very close to $90^{\circ}$, indicate a high p-orbital character within the bonding electron pairs and, as a consequence, high s-character of the electron lone pair of the $\mathrm{Sb}$ atoms. Distibenes $\mathrm{ArSb}=\mathrm{SbAr}$ containing sterically encumbered organic substituents (terphenyl ligands) show significantly larger $\mathrm{C}-\mathrm{Sb}-\mathrm{Sb}$ bond angles between $94.1^{\circ}$ and $105.4^{\circ}$ (7 hits in the CCDC database),$^{[30]}$ resulting from repulsive interactions between the bulky aryl ligands.

Table 2. Selected bond lengths $[\AA]$ and angles $\left[{ }^{\circ}\right]$ of LGaXcoordinated distibenes $[\mathrm{L}(\mathrm{X}) \mathrm{GaSb}]_{2}(\mathrm{X}=\mathrm{Br} \mathbf{1}, \mathrm{I} 2$, OEt 3$)$.

\begin{tabular}{llll}
\hline & $\mathbf{1}$ & $\mathbf{2}$ & $\mathbf{3}$ \\
\hline Sb1-Ga1 & $2.6129(11)$ & $2.5919(5)$ & $2.6012(5)$ \\
Sb2-Ga2 & - & - & $2.5987(5)$ \\
Sb1-Sb1a/2 & $2.6442(11)$ & $2.6310(5)$ & $2.6495(4)$ \\
Ga1-X1 & $2.4126(10)$ & $2.6010(5)$ & $1.830(3)$ \\
Ga2-X2 & - & - & $1.824(3)$ \\
Ga1-N1 & $1.965(3)$ & $1.940(2)$ & $1.962(3)$ \\
Ga1-N2 & $1.959(3)$ & $1.961(2)$ & $1.969(3)$ \\
N1-C1 & $1.334(5)$ & $1.335(3)$ & $1.334(5)$ \\
N2-C3 & $1.335(5)$ & $1.325(3)$ & $1.332(5)$ \\
C1-C2 & $1.412(6)$ & $1.386(4)$ & $1.402(5)$ \\
C2-C3 & $1.396(6)$ & $1.402(4)$ & $1.397(5)$ \\
Ga1-Sb1-Sb1a & $90.92(3)$ & 89.69() & $92.24(2)$ \\
Ga2-Sb2-Sb1 & - & - & $88.31(2)$ \\
Sb1-Ga1-X1 & $116.79(3)$ & 116.21() & $117.87(9)$ \\
Sb2-Ga2-X2 & - & - & $110.26(10)$ \\
N1-Ga1-Sb1 & $121.14(8)$ & $111.88(7)$ & $110.61(9)$ \\
N2-Ga1-Sb1 & $111.57(9)$ & $121.14(6)$ & $121.30(9)$ \\
N1-Ga1-N2 & $96.55(13)$ & $96.64(9)$ & $94.47(13)$ \\
N1-C1-C2 & $123.5(4)$ & $123.0(2)$ & $122.8(3)$ \\
N2-C3-C2 & $122.5(3)$ & $124.2(3)$ & $124.7(4)$ \\
C1-C2-C3 & $129.7(3)$ & $128.9(3)$ & $127.7(4)$ \\
\hline
\end{tabular}

The synthesis of $\mathbf{1}$ - $\mathbf{3}$ demonstrates the high synthetic potential for bond activation reactions of gallanediyl LGa and for the stabilization of unusual bonding properties. It is noteworthy, that reactions of the N-heterocyclic carbene 1,3bis(2,6-diisopropylphenyl)-imidazol-2-ylidene (IPr) with group 15 trihalides $\mathrm{EX}_{3}(\mathrm{E}=\mathrm{P}, \mathrm{Sb}, \mathrm{Bi} ; \mathrm{X}=\mathrm{Cl}, \mathrm{Br})$, which were recently reported by Goichochea et al., ${ }^{[31,32]}$ did not result in the formation of the corresponding dipnictenes. Instead, the reactions of IPr with $\mathrm{PX}_{3}$ yielded $\left[\mathrm{P}_{2}(\mathrm{IPr})_{2} \mathrm{Br}_{3}\right] \mathrm{Br}$, exhibiting a P-P single bond bridged by a bromine atom, ${ }^{[31]}$ whereas the reactions with $\mathrm{EBr}_{3}(\mathrm{E}=\mathrm{Sb}, \mathrm{Bi})$ only gave the simple adducts $\mathrm{IPr}_{-} \mathrm{EBr}_{3},{ }^{[32]}$ while $\mathrm{Sb}-\mathrm{Sb}$ or $\mathrm{Bi}-\mathrm{Bi}$ bond formation was not observed.

To investigate the bonding situation of $\mathbf{1}$ to $\mathbf{3}$ and the electronic nature within the Ga-Sb-Sb-Ga unit in more detail, the structures of $(\mathrm{L}(\mathrm{X}) \mathrm{GaSb}]_{2}(\mathrm{X}=\mathrm{F}, \mathrm{Cl}, \mathrm{Br} \mathbf{1}, \mathrm{I}$ 2, OEt 3) were investigated by quantum chemical calculations at the PBE0/def2-TZVP level of theory. The $i$ Pr-groups were substituted by sterically less demanding Me-groups. 
The resulting structural parameters of the Ga-Sb-Sb-Ga unit coincide well with the experimentally values (table 3 ). $\mathrm{Sb}-\mathrm{Sb}$ bond lengths lay within $0.012 \AA$, Sb-Ga within 0.022 $\AA$, Ga-X within $0.025 \AA$ and Ga-N within $0.032 \AA$ deviation from the experimental values of $\mathbf{1}$ to 3 . The average deviation of the bond angles is greater for Sb-Ga-X $\left(1: 3.69^{\circ}, 2: 4.52^{\circ}\right.$, 3: $\left.3.39^{\circ}\right)$ than for $\mathrm{Ga}-\mathrm{Sb}-\mathrm{Sb}\left(1: 1.72^{\circ}, 2: 0.08^{\circ}, \mathbf{3}: 1.68^{\circ}\right)$, most likely resulting from the replacement of the $i$ Pr-groups by sterically less demanding Me groups.

Table 3. Selected experimental and calculated bond lengths $[\AA]$ and angles $\left[^{\circ}\right]$ of $[\mathrm{L}(\mathrm{X}) \mathrm{GaSb}]_{2}(\mathrm{X}=\mathrm{Br} \mathbf{1}, \mathrm{I} 2$, OEt 3).

\begin{tabular}{llll}
\hline & $\mathbf{1}$ & $\mathbf{2}$ & $\mathbf{3}$ \\
\hline Sb-Gaexp. & $2.6129(11)$ & $2.5919(5)$ & $2.6012(5)$, \\
& 2.621 & 2.613 & 2.653 \\
$\mathrm{Sb}-G a_{\text {calc. }}$ & 2.619 & 2.614 & 2.627 \\
& $2.6442(11)$ & $2.6310(5)$ & $2.6495(4)$ \\
$\mathrm{Sb}-\mathrm{Sb}_{\text {exp. }}$ & 2.632 & 2.636 & 2.627 \\
$\mathrm{Sb}-\mathrm{Sb}_{\text {calc. }}$ & $2.4126(10)$ & $2.6010(5)$ & $1.830(3)$, \\
$\mathrm{Ga}-\mathrm{X}_{\text {exp. }}$ & & & $1.824(3)$ \\
& 2.381 & 2.601 & 1.838 \\
$\mathrm{Ga}-\mathrm{X}_{\text {calc. }}$ & 2.394 & 2.601 & 1.833 \\
& $90.92(3)$ & 89.69() & $92.24(2)$, \\
$\mathrm{Ga}-\mathrm{Sb}-\mathrm{Sb}$ exp. & & & $88.31(2)$ \\
& & 89.7 & 89.3 \\
$\mathrm{Ga}-\mathrm{Sb}-\mathrm{Sb} b_{\text {calc. }}$ & 87.0 & 89.8 & 94.6 \\
& 91.4 & 116.21() & $117.87(9)$, \\
$\mathrm{Sb}-\mathrm{Ga}-\mathrm{X}_{\text {exp. }}$ & $116.79(3)$ & & $110.26(10)$ \\
& & 111.7 & 118.0 \\
$\mathrm{Sb}-\mathrm{Ga}-\mathrm{X}_{\text {calc. }}$ & 110.1 & 111.7 & 116.9 \\
& 116.1 & &
\end{tabular}

The HOMO in the halide-substituted distibenes, which is located on the Ga-Sb-Sb-Ga motif, is dominated by contributions from the $\mathrm{Sb}=\mathrm{Sb}$ double bond $\left(\mathrm{p}_{\mathrm{x}}\right.$ and $\mathrm{p}_{\mathrm{y}}$ orbitals of the $\mathrm{Sb}$ centers). In addition, it shows a small contribution from the Ga-X $\sigma$-orbitals, as derived from Löwdin orbital populations. The LUMO is centered around both $\mathrm{Sb}$ atoms in all cases and is an almost exclusive representation of the $\mathrm{Sb}=\mathrm{Sb} \pi *$-orbitals (Figure 4$)$. The calculated HOMO-LUMO gap energies of $1(274 \mathrm{~kJ} / \mathrm{mol}), 2(281 \mathrm{~kJ} / \mathrm{mol})$ and $3(279$ $\mathrm{kJ} / \mathrm{mol}$ ) correspond to light absorption of $425-437 \mathrm{~nm}$, which explains the observed yellow to green color of the compounds and which agree to the $\pi-\pi^{*}$ absorption bands observed for 1 and 2.
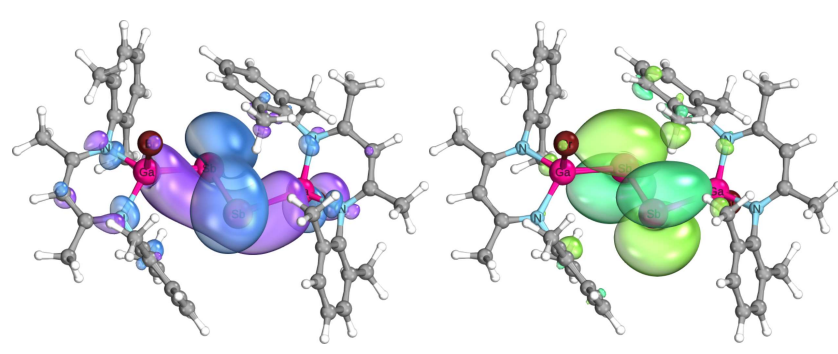

Figure 4. Exemplary HOMO (left) and LUMO (right) of $\mathbf{1}$

The charge distribution in the $(\mathrm{Ga}(\mathrm{X}) \mathrm{Sb})_{2}$ unit is mainly influenced by the halide substituent (X). As was expected, the natural charge of the halide atoms increases with their electronegativity values $(\mathrm{F}:-0.76 e, \mathrm{Cl}:-0.52 e, \mathrm{Br}:-0.50 e, \mathrm{I}$ : $-0.40 e$ ), resulting in a higher positive charge at the gallium center (F: $1.48 e, \mathrm{Cl}: 1.18 e, \mathrm{Br}: 1.14 e, \mathrm{I}: 1.03 e)$. As a result, the charge at the $\mathrm{Sb}$ atom becomes more negative $(\mathrm{F}:-0.15 e$, $\mathrm{Cl}:-0.13 e, \mathrm{Br}:-0.10 e, \mathrm{I}:-0.10 e)$. This is also reflected in the polarization of the $\mathrm{Sb}-\mathrm{Ga}$ bond. The polarization of the bond towards the $\mathrm{Sb}$ center increases in the order $59 \%, 60 \%, 62 \%$ and $63 \%$ from $\mathrm{I}$ to $\mathrm{F}$, in conjunction with the increasing electronegativity of the halide. On the other hand, the electronic character of the $\mathrm{Sb}-\mathrm{Sb}$ and $\mathrm{Sb}-\mathrm{Ga}$ bonding orbitals is not largely influenced by the halide substituent $\mathrm{X}$. The $\mathrm{Sb}$ $\sigma$-bonds have almost $90 \%$ and the $\pi$-bond $99 \%$ p-character in all cases. The Sb lone-pairs also has a constant $76-78 \% \mathrm{~s}-$ character.

The bond polarization of the Sb-O bond and the orbital characters in 3 fall between the values of the $\mathrm{F}$ and $\mathrm{Cl}$ substituted molecules, as was expected from the electronegativity and steric demand of the OEt substituent Only the charge of the $\mathrm{O}$ center is more negative $(-0.96 e)$ than the corresponding $\mathrm{F}(-0.76 e)$, since it can withdraw electron density not only from the Ga but also from the adjacent $\mathrm{C}$ center.

\section{Conclusions}

Distibenes containing a $\mathrm{Sb}=\mathrm{Sb}$ double bond can generally be synthesized by reaction of two equivalents of $\mathrm{LGa}$ with antimony trihalides $\mathrm{SbX}_{3}(\mathrm{X}=\mathrm{Br}, \mathrm{I})$ and triethoxide $\mathrm{Sb}(\mathrm{OEt})_{3}$. The reactions proceed with insertion of two gallandiyls into two $\mathrm{Sb}-\mathrm{X}$ bonds, followed by elimination of $\mathrm{LGaX}_{2}$ and $\mathrm{LGa}(\mathrm{OEt})_{2}$, respectively, and formation of $[\mathrm{L}(\mathrm{X}) \mathrm{GaSb}]_{2} \mathbf{1} \mathbf{- 3}$. Comparable reactions were previously observed between LM $(\mathrm{M}=\mathrm{Al}, \mathrm{Ga})$ and $\mathrm{EX}_{3}$ and $\mathrm{E}\left(\mathrm{NR}_{2}\right)_{3}(\mathrm{E}=\mathrm{As}, \mathrm{Sb}, \mathrm{Bi} ; \mathrm{X}=$ halide), hence this reaction pathway offers a general route to metal-substituted dipnictogenes of the general type $[\mathrm{L}(\mathrm{X}) \mathrm{ME}]_{2 .}{ }^{[17]}$ Quantum chemical calculations with these complexes are currently performed to prove if the $\mathrm{L}(\mathrm{X}) \mathrm{Ga}$ substituents only serve as kinetically stabilizing (sterically demanding) ligand or if dispersion interactions between the ligands, as was recently reported for main group element compounds, ${ }^{[33]}$ also lead to a stabilization of such molecules.

\section{Experimental Section}

General Procedures. All manipulations were performed using Schlenk-line and glove-box techniques under purified argon atmosphere. Toluene and hexane were obtained after passing these solvents through activated alumina columns on an MBraun Solvent Purification System. Deuterated NMR solvents were dried over potassium, purified by distillation, stored over activated molecular sieves $(4 \AA)$ and degassed prior to use. Karl Fischer titration of the dry solvents show values less than $3 \mathrm{ppm}$. $\mathrm{LGa}^{[18]}$ was prepared according to literature methods, whereas $\mathrm{SbBr}_{3}$ and $\mathrm{SbI}_{3}$ were obtained from commercial sources. $\mathrm{Sb}(\mathrm{OEt})_{3}$ was prepared by literature method. ${ }^{[34]}$ Table $\mathrm{S} 1$ summarizes the ${ }^{1} \mathrm{H}$ NMR values of the side-products $\mathrm{LGaX}_{2}(\mathrm{X}=\mathrm{Cl}, \mathrm{Br}, \mathrm{I})$ in $\mathrm{C}_{6} \mathrm{D}_{6}$.

Instrumentation. ${ }^{1} \mathrm{H}(300 \& 500 \mathrm{MHz})$ and ${ }^{13} \mathrm{C}\{1 \mathrm{H}\}(75.5 \mathrm{MHz})$ NMR spectra ( $\delta$ in ppm) were recorded using a Bruker Avance DPX-300 spectrometer and the spectra were referenced to internal $\mathrm{C}_{6} \mathrm{D}_{5} \mathrm{H}\left({ }^{1} \mathrm{H}: \delta=7.154 ;{ }^{13} \mathrm{C}: \delta=128.39\right)$ and $\mathrm{C}_{6} \mathrm{D}_{5} \mathrm{CHD}_{2}\left({ }^{1} \mathrm{H}: \delta=\right.$ $\left.2.09 ;{ }^{13} \mathrm{C}: \delta=20.40\right)$. Microanalyses were performed at the Elemental Analysis Laboratory of the University of DuisburgEssen. IR spectra were measured in an ALPHA-T FT-IR spectrometer equipped with a single reflection ATR sampling module. UV/VIS spectra were recorded with a Varia Carry 300 
The melting points were measured using a Thermo Scientific 9300 apparatus.

General procedure for the synthesis of 1 and 2. LGa (100 mg, $0.205 \mathrm{mmol}$ ) and $\mathrm{SbX}_{3}(\mathrm{X}=\mathrm{Br}, 23.4 \mathrm{mg}, 0.103 \mathrm{mmol}$; I $23.4 \mathrm{mg}$, $0.103 \mathrm{mmol}$ ) were dissolved in $2 \mathrm{~mL}$ of toluene in a Schlenk tube and stirred at room temperature for 2 days. The solution was concentrated in vacuum and $2 \mathrm{~mL}$ of hexane were added. Yellowish-green crystals of $\mathbf{1}$ and $\mathbf{2}$, which were formed upon storage at ambient temperature, were isolated by filtration and recrystallized from toluene solution to afford pure form of $\mathbf{1}$ and $\mathbf{2}$. [L(Br)GaSb $]_{2}$ 1. Yield: $44 \mathrm{mg}(65 \%)$. Mp.: $239^{\circ} \mathrm{C}$ (dec.). Anal. Calcd. for $\mathrm{C}_{58} \mathrm{H}_{82} \mathrm{~N}_{4} \mathrm{Br}_{2} \mathrm{Ga}_{2} \mathrm{Sb}_{2}(\mathrm{M}=1378.15 \mathrm{~g} / \mathrm{mol})$ : $\mathrm{C}, 50.55 \mathrm{H}$, 6.00 N, $4.07 \%$. Found: C, $49.95 \mathrm{H}, 6.07 \mathrm{~N}, 4.24 \%$. Found: C, $49.5 \mathrm{H}, 6.22 \mathrm{~N}, 3.16 \% .{ }^{1} \mathrm{H}$ NMR $\left(\mathrm{C}_{6} \mathrm{D}_{6}, 300 \mathrm{MHz}, 25{ }^{\circ} \mathrm{C}\right): \delta 7.12-$ $6.92\left(\mathrm{~m}, 12 \mathrm{H}, \mathrm{C}_{6} H_{3}-2,6-i-\mathrm{Pr}_{2}\right), 5.00$ (s, $\left.2 \mathrm{H}, \gamma-\mathrm{CH}\right), 3.98$ (sept, ${ }^{3} J_{H-}$ $\left.{ }_{H}=6.7 \mathrm{~Hz}, 4 \mathrm{H}, \mathrm{CH}\left(\mathrm{CH}_{3}\right)_{2}\right), 3.05\left(\mathrm{sept},{ }^{3} \mathrm{~J}_{\mathrm{H}-\mathrm{H}}=6.8 \mathrm{~Hz}, 4 \mathrm{H}\right.$, $\left.\mathrm{CH}\left(\mathrm{CH}_{3}\right)_{2}\right), 1.63(\mathrm{~s}, 12 \mathrm{H}, \mathrm{ArNCCH})_{3}, 1.40\left(\mathrm{~d}, 12 \mathrm{H},{ }^{3} J_{\mathrm{H}-\mathrm{H}}=6.7\right.$ $\left.\mathrm{Hz}, \mathrm{CH}\left(\mathrm{CH}_{3}\right)_{2}\right), 1.20\left(\mathrm{~d}, 12 \mathrm{H},{ }^{3} J_{\mathrm{H}-\mathrm{H}}=6.7 \mathrm{~Hz}, \mathrm{CH}\left(\mathrm{CH}_{3}\right)_{2}\right), 1.12$ (d, $\left.12 \mathrm{H},{ }^{3} J_{H-H}=6.7 \mathrm{~Hz}, \mathrm{CH}\left(\mathrm{CH}_{3}\right)_{2}\right), 0.99\left(\mathrm{~d}, 12 \mathrm{H},{ }^{3} J_{\mathrm{H}-\mathrm{H}}=6.7 \mathrm{~Hz}\right.$, $\left.\mathrm{CH}\left(\mathrm{CH}_{3}\right)_{2}\right) \cdot{ }^{13} \mathrm{C} \mathrm{NMR}\left(\mathrm{C}_{6} \mathrm{D}_{6}, 75 \mathrm{MHz}, 25^{\circ} \mathrm{C}\right): \delta 169.3$ $\left(\mathrm{ArNCCH}_{3}\right), 146.3\left(\mathrm{C}_{6} \mathrm{H}_{3}\right), 142.7\left(\mathrm{C}_{6} \mathrm{H}_{3}\right), 141.2\left(\mathrm{C}_{6} \mathrm{H}_{3}\right), 125.6$ $\left(\mathrm{C}_{6} \mathrm{H}_{3}\right), 124.2\left(\mathrm{C}_{6} \mathrm{H}_{3}\right), 98.4(\gamma-\mathrm{CH}), 29.74\left(\mathrm{CH}\left(\mathrm{CH}_{3}\right)_{2}\right), 28.2$ $\left(\mathrm{CH}\left(\mathrm{CH}_{3}\right)_{2}\right), 28.2\left(\mathrm{CH}\left(\mathrm{CH}_{3}\right)_{2}\right), 25.9\left(\mathrm{CH}\left(\mathrm{CH}_{3}\right)_{2}\right), 24.9\left(\mathrm{CH}\left(\mathrm{CH}_{3}\right)_{2}\right)$, $24.5\left(\mathrm{CH}\left(\mathrm{CH}_{3}\right)_{2}\right), 24.1\left(\mathrm{ArNCCH}_{3}\right)$. IR $\left(v, \mathrm{~cm}^{-1}\right): 3060,3018,2962$, 2923, 2864, 1150, 1518, 1460, 1437, 1385, 1360, 1316, 1289, $1258,1173,1100,1018,935,862,794,771,756,712,635,523$, $441 \mathrm{~cm}^{-1}$. UV/VIS (toluene): $\lambda(\varepsilon)=355(41280), 437 \mathrm{~nm}\left(5377 \mathrm{~m}^{-}\right.$ $\left.{ }^{1} \mathrm{~cm}^{-1}\right)$.

[L(I)GaSb] 2 2._Yield: $49 \mathrm{mg}(67 \%)$. Mp.: $173{ }^{\circ} \mathrm{C}$ (dec.). Anal. Calcd. for $\mathrm{C}_{58} \mathrm{H}_{82} \mathrm{~N}_{4} \mathrm{I}_{2} \mathrm{Ga}_{2} \mathrm{Sb}_{2}(\mathrm{M}=1472.12 \mathrm{~g} / \mathrm{mol}): \mathrm{C}, 47.13 \mathrm{H}$, 6.00 N, $3.79 \%$. Found: C, $47.02 \mathrm{H}, 5.87 \mathrm{~N}, 3.59 \%$. Found: C, $48.0 \mathrm{H}, 5.92 \mathrm{~N}, 3.59 \% .{ }^{1} \mathrm{H}$ NMR $\left(\mathrm{C}_{6} \mathrm{D}_{6}, 300 \mathrm{MHz}, 25^{\circ} \mathrm{C}\right): \delta 7.12-$ 6.99 (m, $\left.12 \mathrm{H}, \mathrm{C}_{6} H_{3}-2,6-i-\mathrm{Pr}_{2}\right), 5.06$ (s, $\left.2 \mathrm{H}, \gamma-\mathrm{CH}\right), 4.04$ (sept, ${ }^{3} J_{H-}$ $\left.{ }_{H}=6.7 \mathrm{~Hz}, 4 \mathrm{H}, \mathrm{CH}\left(\mathrm{CH}_{3}\right)_{2}\right), 3.05\left(\mathrm{sept},{ }^{3} J_{\mathrm{H}-\mathrm{H}}=6.7 \mathrm{~Hz}, 4 \mathrm{H}\right.$, $\left.\mathrm{CH}\left(\mathrm{CH}_{3}\right)_{2}\right), 1.62\left(\mathrm{~s}, 12 \mathrm{H}, \mathrm{ArNCCH}_{3}\right), 1.42\left(\mathrm{~d}, 12 \mathrm{H},{ }^{3} J_{H-H}=6.7\right.$ $\left.\mathrm{Hz}, \mathrm{CH}\left(\mathrm{CH}_{3}\right)_{2}\right), 1.21\left(\mathrm{~d}, 12 \mathrm{H},{ }^{3} J_{H-H}=6.7 \mathrm{~Hz}, \mathrm{CH}\left(\mathrm{CH}_{3}\right)_{2}\right), 1.14$ (d, $\left.12 \mathrm{H},{ }^{3} \mathrm{~J}_{\mathrm{H}-\mathrm{H}}=6.7 \mathrm{~Hz}, \mathrm{CH}\left(\mathrm{CH}_{3}\right)_{2}\right), 0.97\left(\mathrm{~d}, 12 \mathrm{H},{ }^{3} \mathrm{~J}_{\mathrm{H}-\mathrm{H}}=6.7 \mathrm{~Hz}\right.$, $\left.\mathrm{CH}\left(\mathrm{CH}_{3}\right)_{2}\right) .{ }^{13} \mathrm{C} \mathrm{NMR}\left(\mathrm{C}_{6} \mathrm{D}_{6}, 75 \mathrm{MHz}, 25{ }^{\circ} \mathrm{C}\right): \delta 169.4\left(\mathrm{ArNCCH}_{3}\right)$, $146.4\left(\mathrm{C}_{6} \mathrm{H}_{3}\right), 142.9\left(\mathrm{C}_{6} \mathrm{H}_{3}\right), 141.2\left(\mathrm{C}_{6} \mathrm{H}_{3}\right), 125.8\left(\mathrm{C}_{6} \mathrm{H}_{3}\right), 124.3$

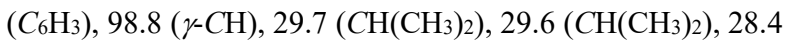
$\left(\mathrm{CH}\left(\mathrm{CH}_{3}\right)_{2}\right), 25.0\left(\mathrm{CH}\left(\mathrm{CH}_{3}\right)_{2}\right), 24.6\left(\mathrm{CH}\left(\mathrm{CH}_{3}\right)_{2}\right), 24.6\left(\mathrm{CH}\left(\mathrm{CH}_{3}\right)_{2}\right)$, $24.2\left(\mathrm{ArNCCH}_{3}\right)$. IR $\left(\mathrm{v}, \mathrm{cm}^{-1}\right): 3060,3018,2962,2922,2864$, 1551, 1519, 1460, 1437, 1385, 1360, 1312, 1286, 1234, 1174, $1098,1057,1018,981,936,862,794,770,756,710,635,524$, $500,438 \mathrm{~cm}^{-1}$. UV/VIS (toluene): $\lambda(\varepsilon)=354(31949), 436 \mathrm{~nm}$ $\left(2656 \mathrm{~m}^{-1} \mathrm{~cm}^{-1}\right)$.

[L(EtO)GaSb] ${ }_{2}$ 3. RGa $(0.116 \mathrm{~g}, 0.239 \mathrm{mmol})$ and $\mathrm{Sb}(\mathrm{OEt})_{3}$ $(0.031 \mathrm{~g}, 20 \mu \mathrm{L}, 0.119 \mathrm{mmol})$ were dissolved in $0.5 \mathrm{~mL}$ of $n$ hexane and stirred at ambient temperature for $2 \mathrm{~h}$ to yield a yellowbrown solution, which was heated at $70{ }^{\circ} \mathrm{C}$ for $1 \mathrm{~h}$ to ensure the reaction completion. Cooling to ambient temperature and storage for $2 \mathrm{~h}$ yielded pale yellow crystals, which were isolated by filtration. Twofold recrystallization from solutions in $n$-hexane $(0.5$ $\mathrm{mL})$ at room temperature finally yielded pure 3. M. p. $216-217^{\circ} \mathrm{C}$. Yield $42 \mathrm{mg}$ (0.032 mmol, $54 \%)$. Anal. Calcd. for $\mathrm{C}_{62} \mathrm{H}_{92} \mathrm{~N}_{4} \mathrm{O}_{2} \mathrm{Ga}_{2} \mathrm{Sb}_{2}$ : C, 56.92; H, 7.09; N, 4.28. Found: C, 56.97; $\mathrm{H}, 7.03$; N, $4.31 \% .{ }^{1} \mathrm{H}$ NMR $\left(\mathrm{C}_{6} \mathrm{D}_{6}, 300 \mathrm{MHz}, 25^{\circ} \mathrm{C}\right): \delta$ 7.14-6.92 $\left(\mathrm{m}, 12 \mathrm{H}, \mathrm{C}_{6} H_{3}-2,6-i-\mathrm{Pr}_{2}\right), 4.83(\mathrm{~s}, 2 \mathrm{H}, \gamma-\mathrm{CH}), 4.03$ (sept, ${ }^{3} J_{H-H}=$ $6.9 \mathrm{~Hz}, 4 \mathrm{H}, \mathrm{CH}\left(\mathrm{CH}_{3}\right)_{2}$ ), 3.90 (quartet, ${ }^{3} J_{H-H}=6.9 \mathrm{~Hz}, 4 \mathrm{H}$, $\mathrm{OCH}_{2} \mathrm{CH}_{3}$ ), 3.01 (sept, $\left.{ }^{3} \mathrm{~J}_{\mathrm{H}-\mathrm{H}}=6.6 \mathrm{~Hz}, 4 \mathrm{H}, \mathrm{CH}\left(\mathrm{CH}_{3}\right)_{2}\right), 1.63$ (s, 12 $\left.\mathrm{H}, \mathrm{ArNCCH}_{3}\right), 1.40\left(\mathrm{~d}, 12 \mathrm{H},{ }^{3} \mathrm{~J}_{\mathrm{H}-\mathrm{H}}=6.6 \mathrm{~Hz}, \mathrm{CH}\left(\mathrm{CH}_{3}\right)_{2}\right), 1.38$ (triplet, $\left.{ }^{3} J_{H-H}=6.6 \mathrm{~Hz}, 6 \mathrm{H}, \mathrm{OCH}_{2} \mathrm{CH}_{3}\right), 1.30\left(\mathrm{~d}, 12 \mathrm{H},{ }^{3} J_{\mathrm{H}-\mathrm{H}}=6.9\right.$ $\left.\mathrm{Hz}, \mathrm{CH}\left(\mathrm{CH}_{3}\right)_{2}\right), 1.05\left(\mathrm{~d}, 24 \mathrm{H},{ }^{3} J_{\mathrm{H}-\mathrm{H}}=6.6 \mathrm{~Hz}, \mathrm{CH}\left(\mathrm{CH}_{3}\right)_{2}\right) .{ }^{13} \mathrm{C}$
NMR $\left(\mathrm{C}_{6} \mathrm{D}_{6}, 75 \mathrm{MHz}, 25^{\circ} \mathrm{C}\right): \delta 168.71\left(\mathrm{ArNCCH}_{3}\right), 145.61$, $142.88,142.49,127.10,124.98,124.23\left(\mathrm{C}_{6} \mathrm{H}_{3}\right), 97.68(\gamma-\mathrm{CH})$, $63.15\left(\mathrm{OCH}_{2} \mathrm{CH}_{3}\right), 29.10\left(\mathrm{CH}\left(\mathrm{CH}_{3}\right)_{2}\right), 27.76\left(\mathrm{CH}\left(\mathrm{CH}_{3}\right)_{2}\right), 26.03$ $\left(\mathrm{CH}\left(\mathrm{CH}_{3}\right)_{2}\right), 25.20\left(\mathrm{CH}\left(\mathrm{CH}_{3}\right)_{2}\right), 25.01\left(\mathrm{CH}\left(\mathrm{CH}_{3}\right)_{2}\right)$,

$24.70\left(\mathrm{CH}\left(\mathrm{CH}_{3}\right)_{2}\right), 24.30\left(\mathrm{ArNCCH}_{3}\right), 21.30\left(\mathrm{OCH}_{2} \mathrm{CH}_{3}\right)$. IR (neat): v 2954, 2925, 2861, 2837, 1558, 1528, 1464, 1441, 1394, 1318, 1260, 1172, 1108, 1061, 1020, 938, 904, 857, 792, 757, 606, 530, $436 \mathrm{~cm}^{-1}$. UV/VIS (toluene): $\lambda(\varepsilon)=354 \mathrm{~nm}\left(16760 \mathrm{~m}^{-1} \mathrm{~cm}^{-1}\right)$.

\section{Single crystal $\mathrm{X}$-ray diffraction.}

Crystallographic data of $\mathbf{1}$ to $\mathbf{3}$, which were collected on a Bruker AXS D8 Kappa diffractometer with APEX2 detector (MoK $\alpha$ radiation, $\lambda=0.71073 \AA$ ) at $296(2) \mathrm{K}(\mathbf{1})$ and $100(2) \mathrm{K}(\mathbf{2}, \mathbf{3})$, are summarized in Table S1 (SI). The solid-state structures of $\mathbf{1}$ to 3 are shown in Figures 1 to 3, bond lengths and angles of $\mathbf{1}$ to $\mathbf{3}$ are summarized in Table 2. The structures were solved by Direct Methods (SHELXS-97) and refined anisotropically by full-matrix least-squares on $\mathrm{F}^{2}$ (SHELXL-2016). ${ }^{[35,36]}$ Absorption corrections were performed semi-empirically from equivalent reflections on basis of multi-scans (Bruker AXS APEX2). Hydrogen atoms were refined using a riding model or rigid methyl groups. The crystals of 1 cracked and lost crystallinity upon cooling. Consequently, the measurement was done at room temperature. Unfortunately, the grease used to mount the crystal was not viscous enough and the crystal slipped during the measurement. As a result, only part of the obtained frames could be successfully integrated, and the completeness of the data set is low.

The crystallographic data of $\mathbf{1}$ to $\mathbf{3}$ (excluding structure factors) have been deposited with the Cambridge Crystallographic Data Centre as supplementary publication nos. CCDC-1827131 (1), and CCDC-1827132 (2). CCDC-1837837 (3) Copies of the data can be obtained free of charge on application to CCDC, 12 Union Road, Cambridge, CB21EZ (fax: (+44) 1223/336033; e-mail: deposit@ccdc.cam-ak.uk).

Supporting Information (see footnote on the first page of this article): A CIF file giving X-ray crystallographic data of $\mathbf{1}$ and $\mathbf{2}$, ${ }^{1} \mathrm{H}$ NMR spectra of $\mathrm{LGaX}_{2}(\mathrm{X}=\mathrm{Cl}, \mathrm{Br}, \mathrm{I})$ as well as spectroscopic details $\left({ }^{1} \mathrm{H},{ }^{13} \mathrm{C}\right.$ NMR; IR, UV/VIS $)$ and crystallographic details of 1 - 3.

\section{Acknowledgement}

Stephan Schulz gratefully acknowledges financial support by the German Research Foundation DFG (project SCHU1069/22-1) and the University of Duisburg-Essen. Financial support by the International Max Planck Research School IMPRS RECHARGE (L.J.) is gratefully acknowledged.

[1] R. West, M. J. Fink, J. Michl, Science 1981, 214, 1343-1344.

[2] M. Yoshifuji, I. Shima, N. Inamoto, K. Hirotsu, T. Higuchi, J. Am. Chem. Soc. 1981, 103, 4587-4589.

[3] a) K. S. Pitzer, J. Am. Chem. Soc. 1948, 70, 2140-2145; b) J. Goubeau, Angew. Chem. 1957, 69, 77-83.

[4] a) P. P. Power, Chem. Rev. 1999, 99, 3463-3503; b) R. C Fischer, P. P. Power, Chem. Rev. 2010, 110, 3877-3923.

[5] a) G. Trinquier, J.-P. Malrieu, J. Am. Chem. Soc. 1987, 109, 5303-5315; b) H. Jacobsen, T. Ziegler, J. Am. Chem. Soc. 1994, 116, 3667-3679; c) H. Grützmacher, T. Fässler, Chem. Eur. J. 2000, 6, 2317-2325; d) J.-D. Guo, D. J. Liptrot, S. Nagase, P. P. Power, Chem. Sci. 2015, 6, 6235-6244; e) D. J. Liptrot, P. P. Power, Nat. Rev. Chem. 2017, 1, 0004.

[6] a) P. P. Power, Nature 2010, 463, 171-177; b) P. P. Power, Chem. Rec. 2012, 12, 238-255; c) S. Yadav, S. Saha, S. S. Sen, ChemCatChem 2016, 8, 486-501. 
[7] a) T. Sasamori, N. Tokitoh, Dalton Trans. 2008, 1395-1408; b) J. D. Protasiewicz, Multiply Bonded Compounds of Group 15 Elements, In Comprehensive Inorganic Chemistry II, 2nd ed., Eds. J. Reedijk, K. Poeppelmeier, Vol. 1, 2013, pp 325348; c) J. S. Jones, B. Pan, F. P. Gabbaï, Group 15 MetalMetal Bonds, in Molecular Metal-Metal Bonds (ed S. T. Liddle), 2015, Wiley-VCH Verlag GmbH \& Co.

[8] Cambridge Structural Database, Version 5.37, see also: F. H. Allen, Acta Cryst. 2002, B58, 380-388.

[9] M. Yoshifuji, Eur. J. Inorg. Chem. 2016, 607-615.

[10] W. Kutzelnigg, Angew. Chem. 1984, 96, 262-286; Angew. Chem. Int. Ed. 1984, 23, 272-295.

[11] a) Y. Wang, G. H. Robinson, Inorg. Chem. 2011, 50, 1232612337; b) D. J. D. Wilson, J. L. Dutton, Chem. Eur. J. 2013, 19, 13626-13637; c) Y. Wang, G. H. Robinson, Inorg. Chem. 2014, 53, 11815-11832; d) R. Kretschmer, D. A. Ruiz, C. E. Moore, A. L. Rheingold, G. Bertrand, Angew. Chem. 2014, 126, 8315-8318; Angew. Chem. Int. Ed. 2014, 53, 8176-8179.

[12] a) N. Tokitoh, Y. Arai, T. Sasamori, R. Okazaki, S. Nagase, H. Uekusa, Y. Ohashi, J. Am. Chem. Soc. 1998, 120, 433-434; b) B. Twamley, C. D. Sofield, M. M. Olmstead, P. P. Power, J. Am. Chem. Soc. 1999, 121, 3357-3367; c) N. Tokitoh, J. Organomet. Chem. 2000, 611, 217-227; d) T. Sasamori, Y. Arai, N. Takeda, R. Okazaki, Y. Furukawa, M. Kimura, S. Nagase, N. Tokitoh, Bull. Chem. Soc. Jpn. 2002, 75, 661-675; e) M. Sakagami, T. Sasamori, H. Sakai, Y. Furukawa, N. Tokitoh, Chem. Asian J. 2013, 8, 690-693; f) D. Dange, A. Davey, J. A. B.Abdalla, S. Aldridge, C. Jones, Chem. Commun 2015, 51, 7128-7131; g) P. K. Majhi, H. Ikeda, T. Sasamori, H. Tsurugi, K. Mashima, N. Tokitoh, Organometallics 2017, $36,1224-1226$.

[13] a) F. A. Cotton, A. H. Cowley, X. Feng, J. Am. Chem. Soc. 1998, 120, 1795-1799; b) P. Vilarrubias, Mol. Phys. 2017, 115, 2597-2604.

[14] T. Sasamori, N. Tokitoh, Dalton Trans. 2008, 1395-1408.

[15] a) C. Jones, Coord. Chem. Rev. 2001, 215, 151-169; b) H. J. Breunig, T. Borrmann, E. Lork, C. I. Raţ, U. Rosenthal Organometallics 2007, 26, 5364-5368.

[16] T. Sasamori, E. Mieda, N. Nagahora, K. Sato, D. Shiomi, T. Takui, Y. Hosoi, Y. Furukawa, N. Takagi, S. Nagase, N. Tokitoh, J. Am. Chem. Soc. 2006, 128, 12582-12588.

[17] a) L. Tuscher, C. Ganesamoorthy, D. Bläser, C. Wölper, S. Schulz, Angew. Chem. 2015, 127, 10803; Angew. Chem. Int. Ed. 2015, 54, 10657; b) L. Tuscher, C. Helling, C. Ganesamoorthy, J. Krüger, C. Wölper, W. Frank, A. S Nizovtsev, S. Schulz, Chem. Eur. J. 2017, 23, 12297; c) L. Tuscher, C. Helling, C. Wölper, W. Frank, A. S. Nizovtsev, S. Schulz, Chem. Eur. J. 2018, 24, 3241-3250.

[18] N. J. Hardman, B. E. Eichler, P. P. Power, Chem. Commun. 2000, 1991-1992.

[19] 1: [ $\left.\mathrm{C}_{58} \mathrm{H}_{82} \mathrm{Br}_{2} \mathrm{Ga}_{2} \mathrm{~N}_{4} \mathrm{Sb}_{2}\right], \quad M=1378.03$, yellowish-green crystal, $(0.183 \times 0.171 \times 0.149 \mathrm{~mm})$; triclinic, space group $P$. $1 ; a=10.487(4) \AA, b=12.427(4) \AA, c=13.362(5) \AA ; \alpha=$ $94.057(18)^{\circ}, \beta=106.627(18)^{\circ}, \gamma=107.006(17)^{\circ}, V=$ 1572.9(10) $\AA^{3} ; Z=1 ; \mu=3.003 \mathrm{~mm}^{-1} ; \rho_{\text {calc }}=1.455 \mathrm{~g} \cdot \mathrm{cm}^{-3}$; 15782 reflections $\left(\theta_{\max }=30.561^{\circ}\right), 8306$ unique $\left(R_{\text {int }}=\right.$ $0.0521) ; 317$ parameters; largest $\max . / \mathrm{min}$ in the final difference Fourier synthesis $1.064 \mathrm{e} \cdot \AA^{-3} /-1.117 \mathrm{e} \cdot \AA^{-3}$; max./min. transmission $0.75 / 0.14 ; R_{1}=0.0455(\mathrm{I}>2 \sigma(\mathrm{I})), w R_{2}$ $=0.1217$ (all data). 2: $\left[\mathrm{C}_{58} \mathrm{H}_{82} \mathrm{Ga}_{2} \mathrm{I}_{2} \mathrm{~N}_{4} \mathrm{Sb}_{2}\right], M=1472.01$, yellowish-green crystal, $(0.085 \times 0.068 \times 0.031 \mathrm{~mm})$; triclinic, space group $P-1 ; a=10.3382(15) \AA, b=12.2802(17) \AA, c=$ 13.153(2) $\AA ; \alpha=93.716(7)^{\circ}, \beta=106.674(6)^{\circ}, \gamma=107.277(6)^{\circ}$, $V=1506.7(4) \AA^{3} ; Z=1 ; \mu=2.834 \mathrm{~mm}^{-1} ; \rho_{\text {calc }}=1.622 \mathrm{~g} \cdot \mathrm{cm}^{-}$ 3; 32391 reflections $\left(\theta_{\max }=30.748^{\circ}\right), 9075$ unique $\left(R_{\text {int }}=\right.$ $0.0432) ; 317$ parameters; largest $\mathrm{max} . / \mathrm{min}$ in the final difference Fourier synthesis $0.891 \mathrm{e} \cdot \AA^{-3} /-0.865 \mathrm{e} \cdot \AA^{-3}$; max. $/$ min. transmission $0.75 / 0.67 ; R_{1}=0.0344(\mathrm{I}>2 \sigma(\mathrm{I})), w R_{2}$ $=0.0640$ (all data). 3: [ $\left.\mathrm{C}_{62} \mathrm{H}_{92} \mathrm{Ga}_{2} \mathrm{~N}_{4} \mathrm{O}_{2} \mathrm{Sb}_{2}\right], M=1308.33$, pale yellow crystal, $(0.236 \times 0.075 \times 0.058 \mathrm{~mm})$; monoclinic, space group $P 21 / c ; a=18.2246(10) \AA, b=15.8444(8) \AA, c=$ $23.0076(12) \AA ; \alpha=90^{\circ}, \beta=106.313(3)^{\circ}, \gamma=90^{\circ}, V=$
6376.2(6) $\AA^{3} ; Z=4 ; \mu=1.716 \mathrm{~mm}^{-1} ; \rho_{\text {calc }}=1.363 \mathrm{~g} \cdot \mathrm{cm}^{-3}$; 216403 reflections $\left(\theta_{\max }=33.217^{\circ}\right), 22332$ unique $\left(R_{\text {int }}=\right.$ $0.0670) ; 671$ parameters; largest $\max . / \mathrm{min}$ in the final difference Fourier synthesis $4.113 \mathrm{e} \cdot \AA^{-3} /-1.452 \mathrm{e} \cdot \AA^{-3}$; max./min. transmission $0.75 / 0.65 ; R_{1}=0.0535(\mathrm{I}>2 \sigma(\mathrm{I})), w R_{2}$ $=0.1458$ (all data).

[20] a) M. Asay, C. Jones, M. Driess, Chem. Rev. 2011, 111, 354396; b) C. J. Allan, C. L. B. Macdonald, Low-Coordinate Main Group Compounds-Group 13. Comprehensive Inorganic Chemistry II, Vol 1, Oxford: Elsevier; 2013, p. 485-566; c) N. J. Hardman, A. D. Phillips, P. P. Power, ACS Symp. Ser. 2002, 822, 2-15.

[21] Cambridge Structural Database, Version 5.37, see also: F.H. Allen, Acta Cryst. 2002, B58, 380-388. 7 hits for $\mathrm{RSb}=\mathrm{SbR}(\mathrm{R}$ defined as "C", co-ordination number of Sb set to 2) were found, which show $\mathrm{Sb}=\mathrm{Sb}$ bond lengths from 2.642 to 2.751 $\AA$ with a mean value of $2.680 \AA$.

[22] Cambridge Structural Database, Version 5.37, see also: F. H Allen, Acta Cryst. 2002, B58, 380-388. 19 distibines $\mathrm{R}_{2} \mathrm{Sb}$ $\mathrm{SbR}_{2}$ (R defined as "C", co-ordination number of Sb set to 3) were found in the Cambridge Structural [Version 5.38, see also: F. H. Allen, Acta Cryst. 2002, B58, 380-388.) with Sb$\mathrm{Sb}$ bond lengths ranging from 2.797 to $3.030 \AA$ with a mean of $2.858 \AA$.

[23] a) S. Nagase, S. Suzuki, T. Kurakake, Chem. Commun. 1990, 1724-1726; b) C.-H. Lai, M.-D. Su, J. Organomet. Chem. 2014, 751, 379-389.

[24] P. Pyykkö, M. Atsumi, Chem. Eur. J. 2009, 15, 186-197.

[25] C. Ganesamoorthy, C. Helling, C. Wölper, W. Frank, E. Bill, G. E. Cutsail III, S. Schulz, Nat. Commun. 2018, 9, 87.

[26] C. Ganesamoorthy, J. Krüger, C. Wölper, A. S. Nizovtsev, S. Schulz, Chem. Eur. J. 2017, 23, 2461-2468.

[27] F. Thomas, S. Schulz, M. Nieger, Eur. J. Inorg. Chem. 2001, 161-166.

[28] S. Schulz, Adv. Organomet. Chem. 2003, 49, 225-317.

[29] J. Krüger, C. Ganesamoorthy, L. John, C. Wölper, S. Schulz, Chem. Eur. J. 2018. DOI: $10.1002 / \mathrm{chem} .201801813$

[30] a) N. Tokitoh, Y. Arai, T. Sasamori, R. Okazaki, S. Nagase, H. Uekusa, Y. Ohashi, J. Am. Chem. Soc. 1998, 120, 433-434; b) B. Twamley, C. D. Sofield, M. M. Olmstead, P. P. Power, $J$ Am. Chem. Soc. 1999, 121, 3357-3367; c) T. Sasamori, Y. Arai, N. Takeda, R. Okazaki, Y. Furukawa, M. Kimura, S. Nagase, N. Tokitoh, Bull. Chem. Soc. Jpn. 2002, 75, 661-675; d) M. Sakagami, T, Sasamori, H. Sakai, Y. Furukawa, N. Tokitoh, Chem. Asian. J. 2013, 8, 690-693.

[31] J. B. Waters, T. A. Everitt, W. K. Myers, J. M. Goicoechea, Chem. Sci. 2016, 7, 6981-6987.

[32] J. B. Waters, Q. Chen, T. A. Everitt, J. M. Goicoechea, Dalton Trans. 2017, 46, 12053-12066.

[33] a) J. P. Wagner, P. R. Schreiner, J. Chem. Theory Comput. 2016, 12, 231-237; b) D. J. Liptrot, P. P. Power, Nat. Rev. Chem. 2017, 1, 0004

[34] The synthesis of $\mathrm{Sb}(\mathrm{OEt})_{3}$ was performed analogously to that of As(OEt) 3. K. Moedritzer, C. O. Denney, J. T. Yoke Inorg. Synth. 1968, 11, 181-183.

[35] G. M. Sheldrick, Acta Crystallogr. 1990, A46, 467-473.

[36] a) G. M. Sheldrick, SHELXL-2014, Program for the Refinement of Crystal Structures University of Göttingen, Göttingen (Germany) 2014; c) G. M. Sheldrick, Acta Crystallogr. 2008, A64, 112-122); d) shelXle, A Qt GUI for SHELXL, C. B. Hübschle, G. M. Sheldrick, B. Dittrich, J. Appl. Cryst. 2011, 44, 1281-1284.

Received: ((will be filled in by the editorial staff)) Published online: ((will be filled in by the editorial staff) 


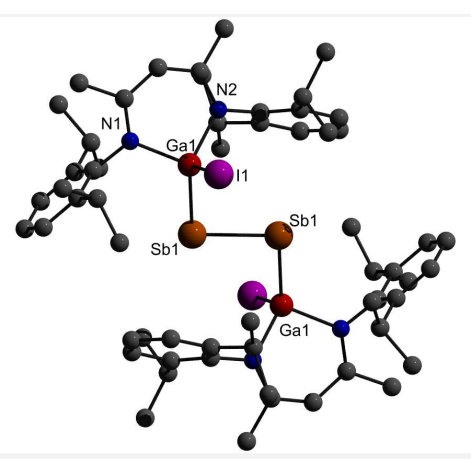

Julia Krüger, Juliane Schoening, Lukas John, Christoph Wölper, and Stephan Schulz * ........ Page No. - Page No.

Synthesis and X-ray crystal structures of Ga-substituted distibenes $[\mathrm{L}(\mathrm{X}) \mathrm{GaSb}]_{2}$ 
DuEPublico

Duisburg-Essen Publications online
DEUISBE U R G

offen im Denken

Ub | universitäts

This text is made available via DuEPublico, the institutional repository of the University of Duisburg-Essen. This version may eventually differ from another version distributed by a commercial publisher.

DOI: $\quad 10.1002 /$ zaac.201800204

URN: urn:nbn:de:hbz:464-20201218-093919-7

This is the peer reviewed version of the following article: Z. Anorg. Allg . Chem. 2018, 644, 1028-1033, which has been published in final form at:

https://doi.org/10.1002/zaac.201800204

All rights reserved. 